\title{
Technology-mediated tasks in the young learners' EFL classroom
}

\author{
Gökçe Kurt, Marmara University, gokce.kurt@marmara.edu.tr ORCID: 0000-0002-9022-1258
}

\begin{abstract}
For the last few decades, technology has been commonly integrated into various foreign/second language teaching contexts. A significant amount of research has been conducted to investigate the effects of technology integration on student learning and demonstrated its effectiveness in improving language areas such as grammar and vocabulary and four language skills as well as in raising cultural awareness, increasing student motivation and autonomy and creating a student-centred learning environment. Despite research interest into the use of technology in education, studies depicting technology-integration practices in young learner classrooms are not many in number. The present quasi-experimental study conducted in the Turkish context aimed to investigate whether the completion of technology-mediated tasks would improve young EFL learners' achievement in listening and reading and writing tests. The analysis of data indicated a higher improvement in the experimental group, compared to the control group who completed traditional homework assignments, but not at a significant level. The study also explored the experimental group learners' opinions about technologymediated tasks they completed and revealed their self-perceived higher ability in English, enhanced selfefficacy beliefs in technology use and positive attitudes towards technology-mediated tasks.
\end{abstract}

Keywords: Technology-mediated tasks, Young learners, EFL.

Received: $18.05 .2020 \quad$ Accepted: 08.10.2020

Published: 01.12.2020

\section{INTRODUCTION}

In the 21st century, rapid and continuous advances in technology have led to significant changes in the nature of education and created a new culture of learning (Thomas \& Brown, 2011). This phenomenon has called for innovative approaches to teaching and learning in all subject areas including English Language Teaching (ELT) in order to meet the needs of new generations of learners. There has been a tremendous shift in the way technology is integrated into ELT due to the wide availability of the Internet, the emergence of interactive and collaborative Web 2.0 tools and the common uses of the social web and mobile technologies (Dudeney \& Hockly, 2012). These emerging technologies have given rise to new forms of communication, text production, collaboration and social networking and led to more creative classroom practices (Kessler, 2019; Mohammad et al., 2018).

Many claims and suggestions have been made about the educational value and potential of various Web 2.0 tools such as blogs, digital storytelling and wikis in enhancing language learning and teaching. Their effectiveness in terms of improving listening ability and pronunciation (e.g. Hawke, 2010; Hubbard, 2017; Istanto, 2011), speaking skills (e.g. Blake, 2017; Saito \& Akiyama, 2017), grammar and vocabulary knowledge (e.g. Gorjian et al., 2011; Groot, 2000; Ma, 2017; Saran et al., 2012; Yüksel \& Tanrıverdi, 2009), reading and writing abilities (e.g. Armstrong \& Retterer, 2008; Arslan \& Sahin-Kizil; 2010; Koçoğlu, 2009; Liaw \& English, 2017), raising cultural awareness (e.g. Elola \& Oskoz, 2008; Pinkman, 2005) as well as increasing learner motivation and autonomy and creating a learner-centred learning environment (e.g. Atay \& Kurt, 2016; Hew \& Brush, 2007; Lindahl \& Folkesson, 2010) has been widely recognised in various second/foreign language teaching contexts. However, the settings of these studies are mostly limited to higher education and adult learners. Studies conducted with young EFL learners are relatively less in number.

Integration of technology in the young learner classroom has been encouraged recognizing that today's children think, behave and learn differently and possess digital skills and competences that set them apart from the previous generations. Being called "digital natives," these children are said to be technologically confident (Nasah et al., 2010; Prensky, 2001) as they are immersed in digital environments and a digital culture. In relation to the use of technology in 
early years of education, the discussion has moved from whether technology should be used in teaching and learning to how it should be integrated to ensure that students' changing learning styles, preferences and needs are met and that they have access to a high-quality educational experience (Bennett \& Maton, 2010; Taghizadeh \& Yourdshahi, 2019). The "how" question necessitates an exploration of the implementation of technology-enhanced instruction in young learner classes of different contexts and observation of how children's learning is being mediated by emerging technologies.

The present study would contribute to the relevant literature by focusing on technology integration in a young learner EFL classroom in Turkey. Specifically, the aim was to explore the effects of completing technology-mediated tasks on young learners' achievement in English and investigate young learners' opinions about technology-mediated tasks they completed. In this study, integration of technology included learners' use of Web 2.0 tools and the Internet to complete a variety of tasks as an out-of-class activity. Adopting a quasi-experimental design, the study was conducted with two intact Grade 4 classes (an experimental and a control group). While the learners in the experimental group completed technology-mediated tasks, the control group learners did traditional paper-based homework assignments as part of the regular English instruction. The following sections of the article review the literature relevant to the scope of the study, present the methodology and discuss the findings by referring to the relevant and recent literature.

\section{LITERATURE REVIEW}

\section{Technology Integration in Young Learner EFL Classrooms}

Young learners have been largely neglected in research on technology-mediated foreign language learning (Lin, 2014). Accordingly, a limited number of studies have investigated technologyimplementation practices in young learner EFL classrooms and examined the influence of such practices on their foreign language development. In one such study, Wong and Hew (2010) explored the impact of blogging and scaffolding on primary school students' narrative writing in Singapore. Data were gathered from 36 Grade 5 students through pre-post writing tests, reflection papers and interviews. Blogging activities included students' typing the first draft of their writing on their individual blogs using the writing guide provided; revising their first drafts in terms of spelling and word count; sharing the revised drafts on the blogs for peer-feedback purposes; and producing the final drafts based on the feedback received. The results revealed that students' mean scores had improved for content and language and for the overall total. The improvement was at a statistically significant level for content and the overall total. Students' comments also revealed their positive attitudes towards using blogs for writing.

Woo et al. (2010) examined the potential effects of a wiki on 38 fifth-grade EFL students' writing abilities in a Chinese primary school. For the purposes of the study, a wiki was created and integrated into the existing English curriculum. The students worked collaboratively on the wiki page to write a non-fiction text about an animal of their choice and added photos and graphics to illustrate their writing. The findings of the study showed students' improved selfperception of their writing ability and enjoyment in working collaboratively on a wiki page.

Leacox and Jackson's study (2014) investigated 24 pre-school and kindergarten English language learners' vocabulary learning in two different reading conditions: adult-reading and technology-enhanced repeated readings. Students in the control group listened to an adult-read storybook in English and were exposed to vocabulary incidentally. The experimental group students, on the other hand, were provided with technology-enhanced English shared reading with Spanish-bridging vocabulary instruction (TESB) with adult mediation in an electronic book. The TESB instruction included multiple vocabulary strategies. For example, students viewed target vocabulary words and listened to their audio-recorded definitions in Spanish as embedded throughout the e-book. The analysis of data revealed that students in the experimental group receiving the TESB instruction gained more vocabulary than the students in the control group.

In a more recent study, Hwang et al. (2016) focused on the impact of storytelling on young EFL learners' speaking skills. In a six-week quasi-experimental study, the experimental group 
learners $(\mathrm{N}=30)$ created stories using a Web-based multimedia storytelling system while the control group learners $(\mathrm{N}=29)$ created stories in a traditional way using paper and pencil. According to the findings, the experimental group learners outperformed the learners in the control group on the post-test assessing their speaking skills. Moreover, they could remember new vocabulary better and practiced speaking skills more frequently. They also expressed positive perceptions and attitudes towards Web-based storytelling.

In a study at an elementary school in Taiwan, Hong et al. (2016) investigated the impact of robot-assisted multimedia instructional materials on EFL learners' learning performance and motivation. During the study, teaching materials were presented to the experimental group ( $\mathrm{N}=$ $25)$ in the display system with a humanoid robot, while the ones used in the control group ( $\mathrm{N}=$ 27) were only displayed through the display system without a robot. The post-test results revealed that the experimental group outperformed the control group, particularly in terms of the improvement in listening and reading skills. Furthermore, the experimental group's learning motivation was positively influenced.

In their experimental study, Çavuş and İbrahim (2016) developed an interactive mobile storytelling application and explored its effectiveness in improving 37 12-year-old students' vocabulary knowledge, pronunciation and listening skills and comprehension ability. During the 4-week study conducted in Cyprus, the students in the experimental group ( $\mathrm{N}=19)$ were engaged with storytelling using the mobile application while the control group students $(\mathrm{N}=18)$ were given the same children's story book in a traditional paper form. As stated in the findings, the experimental group students outperformed the control group students at a significant level in improving their listening, vocabulary, comprehension and pronunciation skills.

In Sun et al. (2017)'s study, a mobile voice-based social-networking site (SNS) was integrated into first-grade EFL classes in China to investigate whether a voice-based mobile SNS environment would improve first graders' EFL speaking performance and how students would perceive practicing English on the mobile SNS. During the study, the same speaking tasks were assigned to both control $(\mathrm{N}=35)$ and experimental groups $(\mathrm{N}=37)$. While the control group students did their oral presentations in class, the experimental group students used an app called Papa which allowed the user to record, upload and share their audio. They recorded their oral assignments and posted them to Papa with relevant pictures. Upon the completion of the treatment, speaking skills of both group students were assessed in terms of accuracy, fluency and pronunciation. The gain in fluency was significantly higher in the experimental group. The experimental group students identified two features of Papa as useful: being heard and having more opportunities to speak.

The findings of the reviewed studies with young EFL learners suggest that using Web 2.0 technologies facilitates student learning, supports the improvement of foreign language skills and creates a learning environment in which students develop positive attitudes towards technologyenhanced instruction. Despite the reported advantages, the actual use of technology in the classroom is still infrequent in many teaching contexts and especially in early education (Blackwell, et al., 2014; Kerckaert et al., 2015). Turkey is one of these contexts where technology is not frequently integrated into young learner English classes despite national and state promotion of educational technology use. The following section describes the Turkish context in detail.

\section{The Turkish Context}

Many countries around the world have been investing in and adopting information technologies to increase the quality of education. Turkey is one of these countries implementing educational and technological initiatives due to political, economic and cultural needs and technological advances in the world. For the last two decades, the Turkish educational system has undergone significant changes. The passage of a law in 1997 introduced the eight-year compulsory education system and public primary school learners started learning English from the fourth grade on (Kirkgoz, 2005). The second significant change occurred in 2012, when the Ministry of National Education (MONE) passed new legislation on primary and secondary education, referred to as $4+4+4$ (primary, middle, high school). This new $4+4+4$ system extended the eight-year 
compulsory education to 12 years and mandated that English instruction be offered from the second grade on, rather than starting in the fourth grade. With the new system, the starting age for language learning decreased from 8-8.5 years of age to 6-6.5 years of age. The new curriculum was designed in close alignment with the Common European Framework of Reference for Languages: Learning, Teaching, Assessment (CEFR), with an emphasis on the importance of using language in an authentic communicative environment to generate real meaning (English Language Curriculum for Primary Education, 2013).

Parallel to the innovations in education, MONE also initiated large-scale projects such as the Basic Education program (BEP) (1998-2007), the Secondary Education program (SEP) (2005-2010) and the Movement to Increase Opportunities and Technology (FATIH) (2010) to increase technology integration. The BEP and the SEP aimed at introducing technology into primary and secondary schools, respectively. Their focus was on equipping schools with computers and computer-related technologies and providing teachers with training on computer skills (MONE, 2008). The FATIH project was announced in 2010 with the objective of increasing quality in education and ensuring equality of opportunity. As stated in the project, primary and secondary schools (almost 600,000 classrooms) across Turkey would be equipped with interactive white boards (IWBs), projectors and printers; teachers and students would be provided with tablets; teachers would receive in-service training on technology integration; and new educational content would be prepared to support technology integration in each course.

Despite the technological reforms enacted so far to improve the quality of education in all levels including primary schools, to date, only one experimental study has reported the impact of a technology-enhanced instruction on foreign language development of Turkish young EFL learners. In their study, Buckingham and Alparslan (2017) aimed to investigate whether out-ofclass speaking practice would contribute to students' speaking proficiency and willingness to communicate. The participants were Grade 3 Turkish learners of English. Students were asked to record their answers to audio-visual speaking activities created by their teachers. Each activity was created using PowerPoint and included a video, voice recordings of the teacher, images and a text. Students also recorded their answers onto the same slide. Recording their responses provided students with asynchronous speaking practice homework. Students in the control group received traditional paper-based exercises as homework. The content of both speaking exercises and traditional exercises was based on the class syllabus. The findings of the speaking test scores revealed that the experimental group students' oral performance improved significantly. Moreover, the experimental group students improved their ability to respond more confidently with minimal pauses and hesitations.

To summarise, although technology is becoming more available in schools and the effectiveness of new technologies in improving foreign language teaching and learning is widely acknowledged, studies depicting technology-integration practices in young learner classrooms are still limited in number. Thus, more research is needed to understand the learning outcomes that technology can enhance and the circumstances under which such an enhancement can be realized in practice in young learner EFL classrooms.

\section{Rationale and Objectives of the Study}

The impetus for the present study came from informal talks between the researcher, the author of this study, and an in-service teacher who was amenable to integrating technology in her primary English classroom effectively. The teacher's use of technology in the classroom was limited to employing it as a presentation tool only. The classroom was equipped with an IWB connected to the Internet. The learners did not have an individual access to any technology in the classroom.

The researcher and the teacher decided to work collaboratively in order to design technology-mediated tasks for the young EFL learners in her classes. Considering the physical environment of the classroom with limited technology access for the learners, tasks were to be completed out-of-class as homework. This 8-week quasi-experimental study with two intact Grade 4 classes (an experimental and a control group) aimed to investigate whether the completion of technology-mediated tasks would improve young Turkish EFL learners' 
achievement in listening and reading and writing tests. The study also focused on the learners' perceptions of the tasks completed. The following research questions were specifically addressed:

(1) Is there a significant difference between experimental group learners who complete the technology-mediated tasks and control group learners who complete traditional homework assignments in terms of their achievement in the listening test?

(2) Is there a significant difference between experimental group learners who complete the technology-mediated tasks and control group learners who complete traditional homework assignments in terms of their achievement in the reading and writing test?

(3) What are the opinions of experimental group learners about the technology-mediated tasks they completed?

\section{METHODS}

\section{Participants and Setting}

The participants were 43 Grade 4 learners in two intact classes in a private primary school in Istanbul, Turkey. At the time of the study, there were four Grade 4 classes and these two classes were randomly selected for the study and assigned to control and experimental conditions, with 21 and 22 students respectively. The learners were all native speakers of Turkish, with an average age of 10 and had been learning English at the same school for five years since kindergarten. In Grade 4, they studied English for eight hours a week. Six hours were taught by a non-native English teacher, while for two hours they were taught by a native-speaker teacher. Both the experimental and control groups were taught by the same non-native teacher who collaborated with the researcher for the present study. The teacher had graduated from the ELT department of a state university in Turkey and was enrolled in an ELT Master's program at the time of the study. She had four years of teaching experience and had been working at the same school since her graduation. As reported by the teacher, the learners came from high-income families and had an access to technologies such as mobile phones, tablets or computers at home. They were highly motivated to use technology and used the computer and the IWB in the classroom to connect to the Internet, to find a video to play or to visit a website.

For ethical considerations, the permission to conduct the present study was obtained from the school administration. Parents provided written consent for their children's participation. Anonymity and confidentiality were guaranteed.

\section{Data Collection and Analysis}

Both quantitative and qualitative data were collected for this mixed-method quasi-experimental study. For the first and second research questions, to understand whether completing technology-mediated tasks would increase learners' achievement in English, quantitative data came from the Cambridge English: Young Learners Tests (CYLET) produced by Cambridge English Language Assessment. The CYLET is for learners in primary and lower secondary education and has three levels of assessment: Starters, Movers and Flyers. As the participating learners had taken the Starters Test in the previous year, the Movers Test was used in this study. The Movers Test had three sections: Listening, Reading and Writing and Speaking. The speaking section was excluded from this study for practicality reasons. The listening and reading and writing sections of the same Movers Test were applied to the learners as pre- and post-tests at the beginning and end of the study, following a two-group pre-test/post-test design.

Data obtained from the Movers Test before and after the study were analysed via SPSS 22 statistical package. The independent samples t-test was applied to the data coming from the pretests to ensure that the experimental and control group learners were at a comparable level in terms of their listening and reading and writing abilities prior to the study and, upon the completion of the tasks, to both group of learners' gain scores in the tests to see whether any significant difference occurred between the groups in terms of their achievement in English. 
For the third research question, to understand learners' opinions about technologymediated tasks, qualitative data were gathered from a semi-structured focus-group interview conducted with five randomly selected learners from the experimental group. The audiorecorded interview was conducted by the non-native teacher during free class time and lasted around 20 minutes. The transcribed interview data were analysed to identify common patterns/themes and divergences within the data following the pattern-coding procedure of Miles et al. (2014). The learners were ascribed numbers that were used in the transcription and report.

\section{Design and Implementation of Technology-mediated Tasks}

For the purposes of the study, six technology-mediated tasks were designed considering the profile and needs of the young EFL learners and the context specific factors. The content of the tasks was based on the class syllabus. In the design process, the following set of criteria suggested by González-Lloret and Ortega (2014) for technology-mediated tasks were followed:

1. The primary focus should be on meaning. In other words, learners should be focused on the meaning and any particular language focus should be implicit to them.

2. Goal-orientation is needed. The task should entail a communicative purpose as well as communicative and/or non-communicative outcomes resulting from task completion.

3. The task should be learner-centred and address the needs and wants of the learners. It should also enable learners to use their own linguistic and non-linguistic resources as well as their digital skills, to allow for flexibility and diversity.

4. The task should be authentic, drawing on real-world processes of language use, integrating form, function, and meaning.

5. The task should provide opportunities for reflection besides offering learners the chance to learn by doing.

González-Lloret and Ortega discuss that these key definitional features of tasks are to guide the process of "choosing ways to recruit technologies and targeting desired affordances within technologies so as to integrate cogently the digital design into the design of tasks for language learning" (p. 6). In this study, first, the tasks were identified following the criteria above. Then, available technologies were evaluated in terms of the affordances and constraints they offered and the ones that best matched with the purposes of each task were incorporated in the study. The following table (Table 1) illustrates the topics and language functions covered, the technology-mediated tasks designed, the Web 2.0 tools employed in the completion of the tasks, and the end products.

Table 1. Technology-mediated tasks used in the present study

\begin{tabular}{|c|c|c|c|c|}
\hline Weeks & $\begin{array}{l}\text { Topics/Language } \\
\text { Functions }\end{array}$ & Technology-mediated Tasks & Web 2.0 Tools used & End products \\
\hline 1 & $\begin{array}{l}\text { People - } \\
\text { Describing people }\end{array}$ & $\begin{array}{l}\text { Creating a podcast describing } \\
\text { a character's physical } \\
\text { appearance. }\end{array}$ & www.voki.com & A podcast \\
\hline 2 & $\begin{array}{l}\text { Daily routines - } \\
\text { Talking about } \\
\text { daily routines }\end{array}$ & $\begin{array}{l}\text { Creating a timeline showing } \\
\text { learners' daily activities with } \\
\text { photos and written } \\
\text { descriptions. }\end{array}$ & $\begin{array}{l}\text { http://www.readwrit } \\
\text { ethink.org/files/resou } \\
\text { rces/ } \\
\text { interactives/timeline_ } \\
2 \text { / }\end{array}$ & A timeline \\
\hline 3 & $\begin{array}{l}\text { A healthy diet - } \\
\text { Giving advice } \\
\text { about healthy } \\
\text { eating }\end{array}$ & $\begin{array}{l}\text { Creating a dialog to give } \\
\text { advice about healthy eating. }\end{array}$ & $\begin{array}{l}\text { http://www.makebeli } \\
\text { efscomix.com/ }\end{array}$ & A comic story \\
\hline
\end{tabular}




\begin{tabular}{lllll}
\hline 4 & $\begin{array}{l}\text { Superheroes - } \\
\text { Talking about } \\
\text { abilities }\end{array}$ & $\begin{array}{l}\text { Creating a hero, describing its } \\
\text { appearance and talking about } \\
\text { his/her likes/dislikes and } \\
\text { abilities. }\end{array}$ & $\begin{array}{l}\text { http://artpad.art.com } \\
\text { /artpad/painter/ } \\
\text { https://vocaroo.com/ }\end{array}$ & $\begin{array}{l}\text { A drawing of a } \\
\text { hero and a } \\
\text { podcast }\end{array}$ \\
\hline $\begin{array}{l}\text { People - } \\
\text { Describing } \\
\text { personality }\end{array}$ & $\begin{array}{l}\text { Writing a 'Who I am' poem for } \\
\text { a character from a story of } \\
\text { their choice and creating a } \\
\text { podcast telling the poem. }\end{array}$ & $\begin{array}{l}\text { http://blabberize.co } \\
\mathrm{m} / \text { make }\end{array}$ & A podcast \\
& $\begin{array}{l}\text { Animal Tales - } \\
\text { Asking and } \\
\text { answering } \\
\text { questions about a } \\
\text { story }\end{array}$ & $\begin{array}{l}\text { animals. } \\
\text { anditital story about }\end{array}$ & www.storybird.com & A digital story \\
& & & \\
\hline
\end{tabular}

The designed tasks were implemented in the experimental group as follows: The teacher introduced the tasks in the last English lesson of the week. In order to facilitate learners' individual task completion process outside the classroom, two handouts were prepared for each task: one in English explaining the task and one in Turkish instructing the learners, with screenshots, on the use of the assigned Web 2.0 tool(s). During the class hour, the teacher referred to the handouts and explained them in detail. The learners were encouraged to take notes. The teacher also demonstrated how to use the tool(s) assigned for the task on the IWB following the steps on the handout. Finally, an example product prepared by the teacher in advance was viewed on the classroom blog specifically created for this study. The whole process lasted around 20-25 minutes. The learners had two days to complete the task at home. When the task was completed, they emailed their end product to the teacher. The products were then uploaded to the classroom blog by the teacher. In the first lesson hour following the weekend, the teacher referred to the learners' products on the blog and invited the learners to briefly talk about or present their work to the class. They were also encouraged to comment on each other's work both on the blog and in the classroom. In relation to the learners' work, the teacher gave a brief feedback, mostly focusing on the content. The same process was repeated for each task for six weeks.

Figures 1 and 2 below display two examples of written end products created by the participant learners for the study purposes. Figure 1 presents a timeline, intentionally pixelated for privacy reasons, created for the task on daily routines while Figure 2 illustrates a digital story about animals.

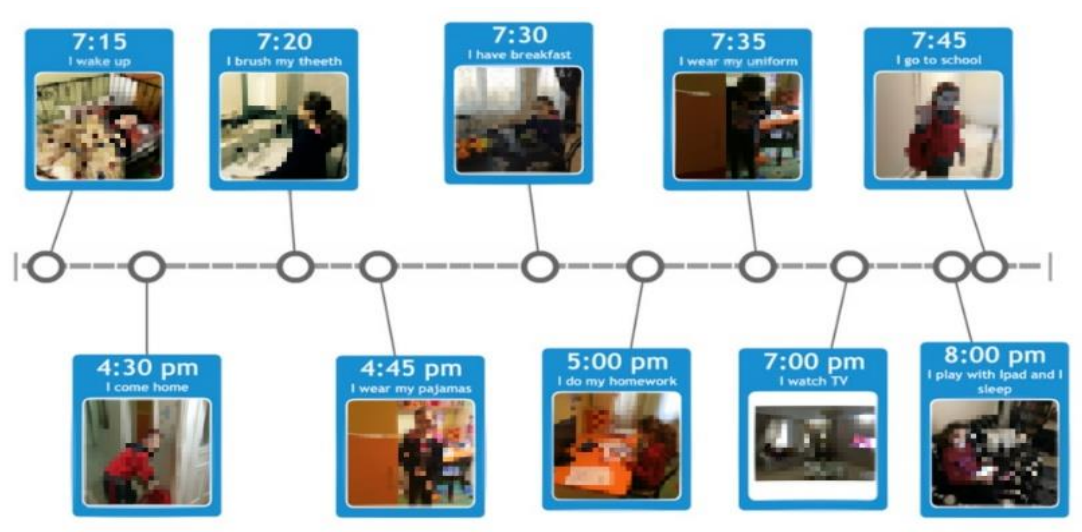

FIGURE 1. A timeline created by a learner in the experimental group 

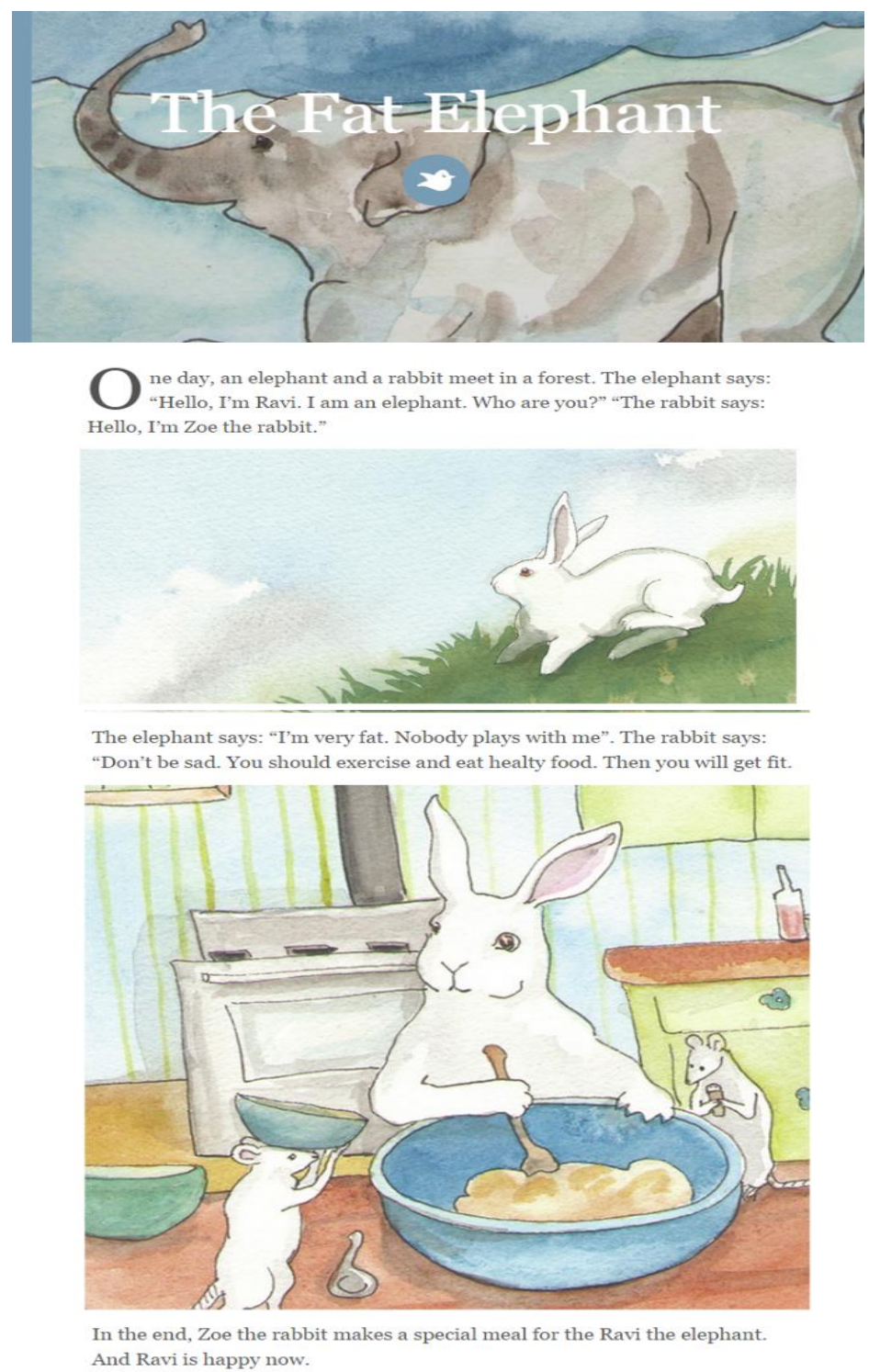

FIGURE 2. A digital story created by a learner in the experimental group

Prior to the study, as part of the regular English instruction, all Grade 4 learners were given a weekend worksheet to practice the topics and language functions covered during the week. The activities usually required a limited amount of writing. That is, learners wrote one word to complete a sentence, matched sentence halves or wrote a short, one clause sentence. Throughout the study, while the experimental group learners worked on technology-mediated tasks, the ones in the control group continued to complete the weekend worksheet as homework. Similar topics and language functions were addressed in the worksheets. For example, while the experimental group students recorded a podcast to describe a character of their choice in terms of its physical appearance, the control group students were given a picture of a character and asked to complete the given sentences by using one word. Or, while the learners in the experimental group created a comic story with two characters giving each other advice about healthy eating, the control group learners responded to the questions of 'What should/shouldn't we eat for a healthy diet?' by writing one-clause sentences. The teacher checked students' answers as a whole class and stated whether the given answer was right or wrong. 


\section{RESULTS}

\section{Learners' Achievement in the Listening Test}

The independent samples t-test was conducted in order to compare the experimental and control group learners' listening test scores prior to the study to ensure that they were at a comparable level. No significant difference was found between the experimental $(M=20.68, S D=1.67)$ and the control groups $(M=20.48, S D=2.11)$ in terms of their listening ability before the study began $(\mathrm{t}(41)=-.355, \mathrm{p}=.73)$.

To find out whether there was a significant difference between the groups at the end of the study, the independent samples t-test was applied to both groups' gain scores in the listening section of the Movers Test. As presented in Table 2 below, the findings revealed an increase in both group of learners' listening performance. The gain in the experimental group was higher than the control group, but not at a statistically significant level.

Table 2. Differences between the groups in terms of their Listening gain scores

\begin{tabular}{|c|c|c|c|c|c|c|}
\hline Group & Test & M & SD & df & $\mathbf{t}$ & p* \\
\hline $\begin{array}{l}\text { Experimental } \\
(\mathrm{N}=22)\end{array}$ & $\begin{array}{l}\text { Pre } \\
\text { Post } \\
\text { Pre } \\
\text { Post }\end{array}$ & $\begin{array}{l}20.68 \\
22.68\end{array}$ & $\begin{array}{l}1.67 \\
1.88 \\
\\
2.11 \\
1.75\end{array}$ & 41 & -1.790 & .081 \\
\hline
\end{tabular}

$* \mathrm{p}<0.05$

\section{Learners' Achievement in the Reading and Writing Test}

Pre-test score comparison of the experimental group $(\mathrm{M}=26.09, \mathrm{SD}=4.43)$ and the control group $(\mathrm{M}=24.24, \mathrm{SD}=5.2)$ revealed that the groups were not different from each other at a significant level in terms of their reading and writing ability prior to the study $(\mathrm{t}(41)=-1.261, \mathrm{p}=.21)$. As can be observed in Table 3 below, the results of the independent $t$-test revealed an improvement from the pre- to the post-reading and writing test scores of the learners in both groups. The gain in the experimental group was higher compared to the gain in the control group, but the difference was not statistically significant.

Table 3. Differences between the groups in terms of their Reading and Writing gain scores

\begin{tabular}{|c|c|c|c|c|c|c|}
\hline Group & Test & $\mathrm{M}$ & SD & $\mathrm{df}$ & $\mathrm{t}$ & p* \\
\hline $\begin{array}{l}\text { Experimental } \\
(\mathrm{N}=22)\end{array}$ & $\begin{array}{l}\text { Pre } \\
\text { Post }\end{array}$ & $\begin{array}{l}26.09 \\
28.14\end{array}$ & $\begin{array}{l}4.43 \\
4.86\end{array}$ & & & \\
\hline $\begin{array}{l}\text { Control } \\
(\mathrm{N}=21)\end{array}$ & $\begin{array}{l}\text { Pre } \\
\text { Post }\end{array}$ & $\begin{array}{l}24.24 \\
25.48\end{array}$ & $\begin{array}{l}5.20 \\
5.36\end{array}$ & 41 & -1.779 & .083 \\
\hline
\end{tabular}

$* \mathrm{p}<0.05$

\section{The Experimental Group Learners' Opinions about Technology-mediated Tasks}

For the third research question, a focus-group interview was conducted with five randomly selected learners from the experimental group in order to gain an in-depth understanding of their opinions about technology-mediated tasks. The analysis of the interview data revealed the following three major patterns: the effectiveness of technology-mediated tasks in improving young EFL learners' foreign language and technology skills, the difficulties they experienced 
during the task-completion process and their feelings about completing technology-mediated tasks.

In relation to the first pattern, all learners agreed on the idea that completing technologymediated tasks contributed to their foreign language development. They referred to the variety and nature of tasks in their explanations. The following responses illustrate their points:

"I think doing different tasks improved my English. For example, when I first recorded myself for a task, I did not like my English. But later it was OK." (L1)

"During the project, I wrote a poem and a story in English. Writing in English was difficult at the beginning, but now I can write many sentences. " (L3)

"I listened to my friends' recordings on the blog. I played them again and again. I didn't understand recordings in English easily. But, I can understand my friends!" (L4)

The learners also perceived that their technological skills improved as they completed the given tasks. Here are some of their comments:

"I learned so many new things in this project. I can record my voice and send emails to my teacher. I can also search the Internet, find different pictures and upload them to the computer. They are easy for me now." (L2)

"I didn't know how to send an e-mail before this study began. I found it difficult to do. Now I can send e-mails easily." (L5)

In relation to the second pattern, as the learners were talking about their experience of the task completion process, they listed the problems encountered and the strategies employed to handle these problems. The problems they mentioned were mainly about technology and language-related. When faced with a problem, the learners sought help from their teacher or a family member or benefitted from the materials provided by the teacher as a scaffold. Here are some of their comments:

"My computer did not have a microphone. I recorded my voice at school with the help of my teacher. I used her computer." (L1)

"I didn't know how to upload the photos to the computer. I got help from my father. We read the handout together and completed the task." (L2)

"When I did not know how to say something in English, I asked for help from my sister." (L4)

"Sometimes I didn't understand the task clearly. Then I checked the example task on the

blog and did mine in a similar way." (L5)

Finally, for the third and the last pattern, the comments of the learners focused on their feelings towards the tasks they completed. As they mentioned, creating different types of products with various technologies and sharing them on the classroom blog for a wider audience contributed to their positive feelings towards technology-mediated tasks and motivated them to continue doing similar tasks.

"The tasks were very enjoyable. I want to do more because I had a lot of fun." (L3)

"Creating new things is very exciting!" (L4)

"I showed our blog to my parents and we looked at my work together. They loved it! I want to do more tasks so that I can share them with my parents." (L5)

"The tasks were cool! Each task was different and we used different tools. This must continue!" (L2)

To wrap up, the findings of the focus-group interview conducted with the randomlyselected experimental group learners revealed their self-perceived higher ability in English, enhanced self-efficacy beliefs in technology use and positive attitudes towards technologymediated tasks.

\section{DISCUSSION and CONCLUSIONS}

The present study focused on the completion of technology-mediated tasks in a young learner EFL classroom in Turkey. The impact of such tasks on learners' listening and reading and writing test scores was explored using a two-group pre-test-post-test quasi-experimental research design. The comparison of the learners' gain scores revealed an improvement in both 
groups' listening and reading/writing performances. The improvement in the experimental group was higher, but not at a significant level.

Although the number of studies focusing on technology-implementation practices in young learner EFL classrooms is limited, the findings have revealed that such practices enhance student learning (e.g. Hong et al., 2016; Hwang et al., 2016; Leacox \& Jackson, 2014; Sun et al., 2017; Woo et al., 2010). The present study also supports the findings of these studies by showing an improvement in the listening and reading and writing performances of a group of young EFL learners. The higher improvement in the experimental group learners' listening and reading and writing scores might be attributed to the nature of the tasks completed throughout the study. Podcasting tasks, for example, might have contributed to the improvement in the young EFL learners' listening test scores. The learners recorded their podcasts and listened to the podcasts created by their teacher and peers on the blog. This way, they had the opportunity to hear themselves speak English and were exposed to the podcasts created by the others. They also presented their products in front of the class and listened to the others' presentations. Similarly, each designed task required some writing on the part of the learners. They wrote descriptions, created poems or stories and read the others' work on the blog. They were also encouraged to write brief comments to each other's work on the blog.

The statistically insignificant finding might be explained by the limited number of tasks completed and the lack of corrective feedback. Throughout the study, experimental group learners completed only six technology-mediated tasks in six weeks. Working with more tasks for a longer time period might have resulted in greater improvement in the young learners' English ability. Moreover, the feedback learners received was limited to positive comments of the teacher and the peers focusing on the content, not form. In Buckingham and Alpaslan's study (2017), the learners received teacher feedback focusing on accuracy and fluency, in addition to supportive general feedback. Receiving such feedback is considered to have contributed to the improvement in the learners' speaking assessment grades. However, such feedback was missing in the present study due to the time constraints.

This study also aimed at investigating the opinions of experimental group learners about the tasks they completed. Their responses during the focus-group interview revealed their positive attitudes towards technology-integrated instruction, similar to the findings of Wong and Hew (2010), Woo et al., (2010), and Hwang et al., (2016), as reviewed above. Using technology to complete different types of tasks and sharing their end products with others have been among the factors influencing the young EFL learners' attitudes towards technology integration.

In the 21st century, technology has become more pervasive among young learners. It is no longer sufficient for the learners of this century to have less access to technology than the teacher. Watching videos or images or taking turns at an IWB is not enough for them. To reach their full potential, learners need to access to a wide array of technological tools and activities that support the development of problem-solving, decision-making, collaboration and creativity skills (Blair, 2012). Prensky (2010) discusses that "to be the most successful at using technology in the classroom, teachers do not need to learn to use it themselves (although they can if they want to). What teachers do need to know is just how technology can and should be used by students to enhance their own learning" (p. 3). The present study allowed young learners of English to be explorers of various technological tools and designers of variety of products. Creating products let them construct their own learning beyond the classroom. The tasks encouraged their problemsolving, decision-making and creativity skills. The learners worked on the tasks at home, struggled with the task requirements and came out with their own solutions to the problems encountered. The products they developed were novel and reflected their creative thinking. Moreover, their products were shared on the classroom blog. Traditionally, students compose their work for the teacher only. In this study, online publishing through the classroom blog created a real audience for students' work and engaged them in the task completion process, as revealed in the focus-group interview. Using technologies to establish authentic audience for student work makes students feel that their work is worth doing, worth sharing and worth reading (Blair, 2012). 
As Scott (2015) posits "technologies in and of themselves do not drive learning. They are of very little use unless the learning task and framework are clearly defined" (p.6). González-Lloret and Ortega (2014) argue that blends of technology and tasks or namely technology-mediated tasks increase student motivation to take risks and use language creatively, expose them to authentic language environments and a large amount of input and promote their active engagement in learning through learning by doing. In this study, the technology-mediated tasks were generated following the criteria by González-Lloret and Ortega (2014) for technology-task integrations. The tasks had a primary focus on meaning. The learners were not instructed to use a particular language structure creating their outcome, that is, they were free to use any language structures or words. For each task, an example outcome was shared on the classroom blog but there was no explicit focus on the structures used. Meeting the criteria of goal-orientation, each task entailed a communicative purpose and an outcome to be completed. The learners worked on the tasks to tell about their daily routine, to write a poem or to tell a story and, accordingly, produced a timeline, a poem or a digital story. Referring to the criteria of learner-centeredness, the designed tasks allowed for flexibility and diversity rather than uniformity in the task processes and means. Although the outcomes produced by the learners were comparable to each other, they reflected their personal choices and creativity. For example, in the story writing task, the learners were free to choose any animal character and decide on the setting and the plot of their stories. They also incorporated visuals into their stories by selecting the images that best matched their stories. The tasks also drew on real-world processes of language use. The learners were concerned with real-world meanings and used the language, for example, to talk about their daily routine or give advice. Finally, the learners presented their work in the classroom and were invited to talk about their experience of the task-completion process, which gave them the opportunity for self-reflection. The learners were also encouraged to reflect on their peers' work both on the blog and in the classroom and provide some feedback.

To conclude, more studies are needed to understand how school-aged children learn a second/foreign language with technology in and out of school (Butler, 2015). The way technology-mediated tasks was implemented in the present study might inform the instructional design and delivery of EFL teachers in similar primary school settings on the development and implementation of technology-mediated tasks inside and outside the classroom to support learners' language learning process.

Further research with a greater number of EFL learners in various contexts and with different language proficiency or computer literacy levels is needed to examine the effectiveness of technology-enhanced language learning in supporting young learners' language development. As mentioned before, the feedback received by the learners on their task outcomes comprised a general supportive comment such as 'Good work' or 'Well done' and/or a comment related to the content, i.e., 'a very interesting story.' In other words, the learners did not receive corrective feedback and were not encouraged to check their output for accuracy. Therefore, a further study can be conducted to investigate how providing form-focused feedback on young learners' spoken and written products would impact their achievement in English. Finally, implementing more tasks for a longer time period would increase the effectiveness of such instruction in young learner EFL classes.

\section{REFERENCES}

Armstrong, K., \& Retterer, O. (2008). Blogging as L2 writing: A case study. AACE Journal, 16(3), $233-251$.

Arslan, R. Ş., \& Şahin-Kızıl, A. (2010). How can the use of blog software facilitate the writing process of English language learners? Computer Assisted Language Learning, 23(3), 183-197.

Atay, D. \& Kurt, G. (2016). The effects of podcasting on Turkish pre-service teachers' foreign language anxiety and attitudes towards technology. In M. Rahman (Ed.), Integrating technology and culture: Strategies and innovations in ELT (pp. 152-170). Jaipur: Yking Books.

Bennett, S., \& Maton, K. (2010). Beyond the 'digital natives' debate: Towards a more nuanced understanding of students' technology experiences. Journal of Computer Assisted Learning, 26(5), 321-331. 
Blackwell, C. K., Lauricella, A. R., Wartella, E., Robb, M., \& Schomburg, R. (2013). Adoption and use of technology in early education: The interplay of extrinsic barriers and teacher attitudes. Computers and Education, 69, 310-319.

Blackwell, C. K., Lauricella, A. R., Wartella, E. (2014). Factors influencing digital technology use in early childhood education. Computers and Education, 77, 82-90.

Blair, N. (2012). Technology Integration for the New 21st Century Learner. Principal. January/February, 8-13.

Buckingham, L. \& Alparslan, L. S. (2017). Promoting speaking proficiency and willingness to communicate in Turkish young learners of English through asynchronous computer-mediated practice. System, 65, 25-37.

Butler, Y. G. (2015). The use of computer games as foreign language learning tasks for digital natives. System, 54, 91-102.

Cavus, N., \& Ibrahim, D. (2017). Learning English using children's stories in mobile devices. British Journal of Educational Technology, 48(2), 625-641.

Dudeney, G., \& Hockly, N. (2012). ICT in ELT: How did we get here and where are we going? ELT Journal, 66(4), 533-542.

Elola, I., \& Oskoz, A. (2008). Blogging: Fostering intercultural competence development in foreign language and study abroad contexts. Foreign Language Annals, 41(3), 454- 477.

Gonzalez-Lloret, M. \& Ortega, L. (2014). Towards technology-mediated TBLT: An introduction. M. GonzalezLloret \& L. Ortega (Ed.). Technology-mediated TBLT: Researching technology and tasks (1-22). Amsterdam: John Benjamins.

Gorjian, B., Moosavinia, S. R., Ebrahimi Kavari, K., Asgari, P., \& Hydarei, A. (2011). The impact of asynchronous computer-assisted language learning approaches on English as a foreign language high and low achievers' vocabulary retention and recall. Computer Assisted Language Learning, 24(5), 383-391.

Groot, P. J. (2000). Computer assisted second language vocabulary acquisition. Language Learning \& Technology, 4(1), 60-81.

Hawke, P. (2010). Using internet-sourced podcasts in independent listening courses: Legal and pedagogical implications. Jalt CALL Journal, 6(3), 219-234.

Hew, K. F., \& Brush, T. (2007). Integrating technology into K-12 teaching and learning: Current knowledge gaps and recommendations for future research. Educational Technology Research and Development, 55(3), 223-252.

Hong, Z. W., Huang, Y. M., Hsu, M., \& Shen, W. W. (2016). Authoring Robot-Assisted Instructional Materials for Improving Learning Performance and Motivation in EFL Classrooms. Educational Technology \& Society, 19(1), 337-349.

Hubbard, P., \& Levy, M. (2016). Theory in computer assisted language learning research and practice. In Farr F., and Murray L. (Eds.), The Routledge Handbook of Language Learning and Technology (pp. 24-38). New York, NY: Routledge.

Hwang, W. Y., Shadiev, R., Hsu, J. L., Huang, Y. M., Hsu, G. L., \& Lin, Y. C. (2016). Effects of storytelling to facilitate EFL speaking using Web-based multimedia system. Computer Assisted Language Learning, 29(2), 215-241.

Istanto, J. W. (2011). Pelangi Bahasa Indonesia podcast: What, why and how. Electronic Journal of Foreign Language Teaching, 8(1), 371-384.

Kerckaert, S., Vanderlinde, R. \& van Braak, J. (2015). The role of ICT in early childhood education: Scale development and research on ICT use and influencing factors. European Early Childhood Education Research Journal, 2(2), 183-199.

Kocoglu, Z. (2010). WebQuests in EFL reading/writing classroom. Procedia-Social and Behavioral Sciences, 2(2), 3524-3527.

Kırkgoz, Y. (2005). English language teaching in Turkey: Challenges for the 21st century. In G. Braine (Ed.), Teaching English to the world: History, curriculum and practice (pp. 159-175). Mahwah, NJ: Lawrence Erlbaum Associates.

Leacox, L., \& Wood Jackson, C. (2014). Spanish vocabulary-bridging technology-enhanced instruction for young English language learners' word learning. Journal of Early Childhood Literacy, 142(2), 175-197.

Liaw, M. L., \& English, K. (2017). Technologies for teaching and learning L2 reading. In Chapelle C. A. \& Sauro S. (Eds.), The handbook of technology and second language teaching and learning (pp. 6276). Hoboken, NJ: Wiley Blackwell.

Lin, H. (2014). Establishing an empirical link between computer-mediated communication (CMC) and SLA: A meta-analysis of the research. Language Learning \& Technology, 18(3), 120-147. 
Ma, Q. (2017). Technologies for teaching and learning L2 vocabulary. In Chapelle C. A., \& Sauro S. (Eds.) The handbook of technology and second language teaching and learning (pp. 45-61). Hoboken, NJ: Wiley Blackwell.

Miles, M. B., Huberman, M., \& Saldana, J. (2014). Qualitative data analysis: A methods sourcebook. SAGE Publications.

Nasah, A., DaCosta, B., Kinsell, C., \& Seok, S. (2010). The digital literacy debate: an investigation of digital propensity and information and communication technology. Educational Technology Research and Development, 58(5), 531-555.

Pinkman, K. (2005). Using blogs in the foreign language classroom: Encouraging learner independence. The Jalt CALL Journal, 1(1), 12-24.

Prensky, M. (2001). Digital natives, digital immigrants. On the Horizon, 9(5).

Prensky, M. R. (2010). Teaching digital natives: Partnering for real learning. Corwin Press.

Saito, K. \& Y. Akiyama (2017). Video-based interaction, negotiation for comprehensibility, and second language speech learning: A longitudinal study. Language Learning, 67(1), 43-74.

Saran, M., Seferoğlu, G., \& Çağıltay, K. (2012). Mobile language learning: Contribution of multimedia messages via mobile phones in consolidating vocabulary. The Asia-Pacific Education Researcher,

21(1), 181-190.

Scott, L. C. (2015). The futures of learning 2: What kind of learning for the 21st century? UNESCO Education Research and Foresight Working Papers Series. Retrieved from http://unesdoc.unesco.org/images/0024/002429/24 2996E.pdf

Sun, Z., Lin, C. H., You, J., Shen, H. J., Qi, S., \& Luo, L. (2017) Improving the English-speaking skills of young learners through mobile social networking, Computer Assisted Language Learning, 30(3-4), 304-324.

Taghizadeh, M., \& Hasani Yourdshahi, Z. (2019). Integrating technology into young learners' classes: language teachers' perceptions. Computer Assisted Language Learning, 1-25.

Thomas, D. \& Brown, J. S. (2011). A New Culture of Learning. CreateSpace.

Woo, M., Chu, S., Ho, A., \& Li, X. (2010). Collaborative writing with a wiki in a primary five English classroom. Managing Knowledge for Global and Collaborative Innovations, 8, 193-206. 